\title{
Improving the carbon footprint of water treatment with renewable energy: a Western Australian case study
}

\author{
Wahidul K. Biswas ${ }^{1 *}$ and Pauline Yek ${ }^{2}$
}

\begin{abstract}
A life cycle assessment (LCA) was carried out on three separate drinking water production options - a groundwater treatment plant (GWTP), surface water treatment plant and seawater desalination plant (electrodialysis) in order to calculate the carbon footprint associated with each process and to identify the areas of production with high levels of GHG emissions in order to develop strategies for reducing their carbon footprint. The results obtained from the LCA show that the highest GHG emissions are from the seawater desalination plant via electrodialysis (ED) where the GHG emissions were $2.46 \mathrm{~kg} \mathrm{CO}_{2}$ equivalent (eq). By comparison, the GWTP has the lowest carbon footprint emitting some $0.38 \mathrm{~kg} \mathrm{CO}$, eq for water delivery to households. The GHG emission contribution of electricity generation for the GWTP, surface water treatment plant and seawater ED plants was 95,82 and $98 \%$, respectively. Furthermore, the GHG emissions associated with this production process can be further reduced by including renewable energy power generation in its operations.
\end{abstract}

Keywords: LCA, Carbon footprint, Water supply options

\section{Background}

In Western Australia (WA), the water flows were dropped significantly during 1997-2005 from an annual average of 161GL (1974-1997) to 115GL per year (Perth Seawater Desalination Plant 2006). This is mainly due to the low rainfall and the climate change initiating the drought. Moreover, the demand on drinking water supply is also increasing owing to the rapid growth of the populations with the estimation around 3.5 million people by the middle of the century (Taylor 2010). Therefore, under the pressure of drought-stricken and rapid expansion of the populations, it is predicted there will be imbalanced between the water supply and the public demand if nothing is done either to decrease the water demand or to improve the efficiency of water supply by 2030. In forecast, the water demand will exceed the water supply by 100GL on annual basis by 2030 (Mercer 2009).

\footnotetext{
*Correspondence: w.biswas@curtin.edu.au

1 Sustainable Engineering Group, Curtin University, Perth, WA 6102, Australia

Full list of author information is available at the end of the article
}

The Integrated Water Supply Scheme (IWSS) is the system that delivers water to over 2 million people in Perth, the Goldfields and Agricultural region and some parts of the South West each year. In 2014-2015, 17 \% of water supplied into the IWSS came from surface water (from dams), $42 \%$ from groundwater and $41 \%$ from desalinated seawater (Water Corporation 2015). While less water will come from dams and more from desalination to secure groundwater sources in the future, the capacities of three currently used water supply options, including Wanneroo groundwater treatment plant (GWTP), surface water treatment plant and seawater desalination plant, need to be increased due to this decreasing water flows and increasing demand on drinking water supply in Western Australia.

The demand for electricity and chemicals for operating these treatment plants will increase to meet the future water demand. Consequently, GHG emissions associated with increased energy and chemical consumption will increase due to increase in the water treatment capacities of these plants. It is therefore important to use an environmental management tool that will allow to identify 
environmental mitigation opportunities in the water treatment process.

Life cycle assessment has widely been used to assess GHG emissions and other associated environmental impacts for water supply and wastewater treatment options in Australia and elsewhere in the world (Barber 2008; Coday et al. 2015; de Haas et al. 2009; Foley et al. 2007; Foley et al. 2010; Hall et al. 2011; Raluy et al. 2005; Stokes and Horvath 2006; Lane et al. 2010; Lundie et al. 2004; Racoviceanu et al. 2007; Shahabi et al. 2015a; Yoshida et al. 2013). None of them have calculated the net GHG emissions from all existing and alternative water supply options in Western Australia. However, it is important for the policy makers such as Water Corporation of WA to devise strategies to meet the increased demand of water with minimum environmental degradation.

In the case of WA, Hardisty et al. (2013) determined economically optimal wastewater treatment and discharge strategies by monetizing financial, environmental and societal values of six water treatment options. Ho and Anda (2006) discussed the overall sustainability benefit of the use of decentralized wastewater treatment system over the centralized system in WA, but they did not determine the life cycle environmental benefits, such as carbon footprint and embodied energy consumption. Thompson and Waite (2003) studied the environmental impact of the discharge of treated water to coastal marine ecosystem. In-depth studies have been carried out for centralized and decentralized seawater reverse osmosis (RO) desalination options taking into account life cycle assessment, economic feasibility, location of seawater, scale of production and clean energy sources considerations for WA (Shahabi et al. 2014; Shahabi et al. 2015a, b, c).

As the LCA of reverse osmosis desalination options has already been considered for WA (Biswas 2009; Shahabi et al. 2014), an LCA has been carried out in order to estimate the carbon footprint of other exiting options in WA including groundwater and surface water supply options and to identify hot spots for finding GHG mitigation opportunities of these options.

In addition to existing GWTP and surface water treatment plant, the current paper also considers the estimation of GHG emissions from another promising alternative water supply option which is a desalination plant via electrodialysis (ED). Although RO is usually preferred to ED due to the handling of large volume of flow rates, the advantages of ED over $\mathrm{RO}$ are the usage of less chemicals during pre-treatment, longer life expectancy and operation at low-to-moderate pressure (AFFA 2002).

This proposed LCA is important as it will enable to compare the environmental performance in terms of GHG emissions from groundwater (or GWTP), surface water and electrodialysis treatment processes. The proposed research will compare the GHG emissions of drinking water production from desalination plant (Biswas 2009) with that produced from GWTP, surface water treatment and ED plants. These outputs could provide additional information to Water Corporation to make a strategic decision in the implementation of less carbonintensive water supply options.

The available published literature have shown that the use of fossil energy contributed significant portion ( $>90 \%$ ) of the total GHG emissions from the water treatment process (Racoviceanu et al. 2007; Biswas 2009). However, the replacement of fossil energy with renewable energy could reduce the GHG emissions significantly by more than $90 \%$. Thus, this paper has assessed whether this electricity has been the hotspot for existing groundwater and surface supply options.

Firstly, this paper presents the carbon footprint of three water supply options. Secondly, it has found out the most GHG emitting life cycle stage requiring further investigation to find mitigation strategy. Thirdly, this paper has found out electricity as the hotspot for three water supply options. Finally, an estimation has been made as to what amount of GHG emissions can be avoided from the most emitting option due to the use of available renewable energy resources.

\section{Methods}

The methodology that has been used for evaluating the LCA of different water sources associated with the technology used for the water supply options is based on ISO 14040-44 guideline (ISO 2007). The components of LCA that follows the ISO guideline are as follows: (1) goal and scope, (2) life cycle inventory, (3) life cycle impact assessment and (4) interpretation.

\section{Goal and scope}

The goal is to compare the global warming performance or carbon footprint of water production for residential sector for different sources of energy used in three water treatment plants in Western Australia. A functional unit is needed for quantifying the inputs of water production during the life cycle. The functional unit (FU) of this study is $1 \mathrm{~m}^{3}$ of scheme or treated water supplied to residential house, and this FU has in fact used to determine the scope or system boundary. The current study only considered the delivery of treated water to tap. It does not take into account the type of end-use appliances such as the type of smart shower head used. Nonetheless, the assessment of the carbon footprint on the capital equipment such as piping system, storage tank, building and machinery are not included due to their long life span (Biswas 2009). 


\section{Life cycle inventory (LCI)}

LCI analysis is a prerequisite to carry out an LCA analysis. LCI takes into account all inputs and outputs required for all stages until the amount of water consumed by the household. The LCI developed consisted of energy and chemicals of water extraction, water treatment and the water distribution stages. Tables 1,2 and 3 show three life cycle inventories for groundwater, surface water and desalination systems to produce and deliver the same amount of drinking water supply (Water Corporation 2011). These tables show the raw or reference data which were used to work out the amount of inputs for the production and delivery of $1 \mathrm{~m}^{3}$ of scheme water from three different sources The LCIs for these three water treatment processes have been discussed as follows:

Wanneroo groundwater treatment plant (GWTP) was operated in the conventional water treatment route where aeration, coagulation, clarification and filtration steps are involved. Nonetheless, the dissolved organic carbon (DOC) in the freshwater at the end of the whole treatment process is up to $5 \mathrm{mg} / \mathrm{L}$ even though the enhancement on the coagulation stage is made especially during the periods of high flow (Lange et al. 2011). Therefore, the Magnetic Ion Exchange (MIEX ${ }^{\circledR}$ ) DOC process has recently been introduced by Orica Watercare, South Australia Water Corporation and the CSIRO prior to the coagulation in order to remove the DOC (Bourke et al. 2011). Figure 1 shows the process flow for the MIEX ${ }^{\circledR}$ water treatment plant. The amount of inputs required for aeration, coagulation, clarification and filtration processes (Fig. 1) or an LCI is presented in Table 1 in order to calculate the GHG emissions associated with the production and use of these inputs.

For the surface water treatment plant, the first step for the water treatment is the screening process. The main purpose of screening is to remove the gross debris and contaminants. This is followed by removing taste- or odor-causing matters as well as preliminary disinfection through pre-oxidization by using chlorine. This stage is known as pre-chlorination. The smaller particles are removed in the next step where alum and polymer are added to promote particle agglomeration in the flocculation and coagulation process. Therefore, the smaller particles can be removed in the sedimentation and filtration steps easily. Finally, the second disinfection step is carried out to kill any remaining disease-causing organism. Table 2 shows the LCI consisting of inputs for pre-chlorination, flocculation and coagulation and sedimentation and filtration processes.

Electrodialysis (ED) process is commonly applied in the drinking and process water treatment plant from brackish water and seawater, treatment of industrial effluents and salt production. Since this process has not been used by Water Corporation, the basic concept for operating the plant was obtained from Sadrzadeh and Mohammadi (2007). For an ED unit, it consists of a number of anion exchange membranes and cation exchange membranes (AEM and CEM) and being assemble alternatively in between an anode and a cathode electrode. When the driving force of

Table 1 Life cycle inventory for Wanneroo GWTP for $1 \mathrm{~m}^{3}$ of water production and delivery

\begin{tabular}{|c|c|c|c|c|c|}
\hline Inputs & Reference quantity & Unit & Calculated quantity & Unit per $\mathrm{m}^{3}$ & References \\
\hline \multicolumn{6}{|l|}{ Extraction process } \\
\hline Energy for pumping system & 0.041 & kWh/kL & 0.041 & kWh & Goldstein and Smith (2002) \\
\hline \multicolumn{6}{|l|}{ Pre-treatment process } \\
\hline Spray aeration & 0.012 & kWh/kL & 0.012 & kWh & Goldstein and Smith (2002) \\
\hline MIEX ${ }^{\circledR}$ resin & 2.667 & $\mathrm{~mL}$ resin/year/person & 2.8 & $\mathrm{~mL}$ & Bourke et al. (2011) \\
\hline Chlorine & 4.800 & $\mathrm{mg} / \mathrm{L}$ & 5.1 & $g$ & Cadee et al. (2011) \\
\hline \multicolumn{6}{|l|}{ Coagulation clarification } \\
\hline Alum & 20.000 & $\mathrm{mg} / \mathrm{L}$ & 0.2 & $\mathrm{~kg}$ & Bourke et al. (2011) \\
\hline Polymer & 0.700 & $\mathrm{mg} / \mathrm{L}$ & 0.74 & g & Cadee et al. (2011) \\
\hline Energy for treatment & 0.020 & kWh/kL & 0.02 & kWh & Goldstein and Smith (2002) \\
\hline Energy for sludge handling & 0.006 & $\mathrm{kWh} / \mathrm{kL}$ & 0.007 & kWh & Goldstein and Smith (2002) \\
\hline $\mathrm{NaCl}$ solution & 90.000 & $\mathrm{~g} / \mathrm{L} \mathrm{MIEX}^{\circledR}$ resin & 0.25 & $g$ & Slunjski, Cadee and Tattersall (2011) \\
\hline \multicolumn{6}{|l|}{ Filtration } \\
\hline Chlorine & $2-10$ & $\mathrm{mg} / \mathrm{L}$ & 6.3 & $g$ & Water Treatment Chemicals (2009) \\
\hline Fluorine & $0.7-1.2$ & $\mathrm{mg} / \mathrm{L}$ & 1.0 & $g$ & Water Treatment Chemicals (2011) \\
\hline Energy consumption & 0.000079 & kWh/kL & 0.000079 & kWh & Goldstein and Smith (2002) \\
\hline \multicolumn{6}{|l|}{ Distribution process } \\
\hline Energy consumption & 0.318 & kWh/kL & 0.318 & kWh & Goldstein and Smith (2002) \\
\hline
\end{tabular}


Table 2 Life cycle inventory for surface water treatment plant for $1 \mathbf{~ m}^{3}$ of water production and delivery

\begin{tabular}{|c|c|c|c|c|c|}
\hline Inputs & Reference quantity & Unit & Calculated quantity & Unit per $\mathrm{m}^{3}$ & References \\
\hline \multicolumn{6}{|l|}{ Extraction process } \\
\hline Energy for pumping system & 0.032 & $\mathrm{kWh} / \mathrm{kL}$ & 0.032 & kWh & Goldstein and Smith (2002) \\
\hline \multicolumn{6}{|l|}{ Pre-chlorination process } \\
\hline Chlorine & 4.800 & $\mathrm{mg} / \mathrm{L}$ & 5.05 & g & Cadee et al. (2011) \\
\hline \multicolumn{6}{|c|}{ Flocculation and coagulation process } \\
\hline Alum & $10-90$ & $\mathrm{mg} \mathrm{Fe}^{3+} / \mathrm{L}$ & 52.63 & $\mathrm{~g} \mathrm{Fe}^{3+}$ & Water Treatment Chemicals (2009) \\
\hline Polymer & 0.700 & $\mathrm{mg} / \mathrm{L}$ & 0.74 & $g$ & Cadee et al. (2011) \\
\hline Energy for treatment & 0.020 & $\mathrm{kWh} / \mathrm{kL}$ & 0.020 & kWh & Goldstein and Smith (2002) \\
\hline Energy for sludge handling & 0.006 & $\mathrm{kWh} / \mathrm{kL}$ & 0.0 .006 & kWh & Goldstein and Smith (2002) \\
\hline \multicolumn{6}{|c|}{ Sedimentation and filtration process } \\
\hline Lime & $10-20$ & $\mathrm{mg} / \mathrm{L}$ & 15.8 & g & Water Treatment Chemicals (2011) \\
\hline Chlorine & $2-10$ & $\mathrm{mg} / \mathrm{L}$ & 6.3 & $\mathrm{~g}$ & Water Treatment Chemicals (2009) \\
\hline Fluorine & $0.7-1.2$ & $\mathrm{mg} / \mathrm{L}$ & 1.0 & $g$ & Water Treatment Chemicals (2011) \\
\hline Energy consumption & 0.00004 & kWh/kL & 0.00004 & kWh & Goldstein and Smith (2002) \\
\hline \multicolumn{6}{|l|}{ Distribution process } \\
\hline Energy consumption & 0.318 & $\mathrm{kWh} / \mathrm{kL}$ & 0.318 & kWh & Goldstein and Smith (2002) \\
\hline
\end{tabular}

Table 3 Life cycle inventory for seawater desalination plant via electrodialysis for $\mathbf{1} \mathbf{m}^{\mathbf{3}}$ of water production and delivery

\begin{tabular}{|c|c|c|c|c|c|}
\hline Inputs & Reference quantity & Unit & Calculated quantity & Unit per $\mathrm{m}^{3}$ & References \\
\hline \multicolumn{6}{|l|}{ Extraction process } \\
\hline Energy for pumping system & 0.032 & $\mathrm{kWh} / \mathrm{kL}$ & 0.032 & kWh & Goldstein and Smith (2002) \\
\hline \multicolumn{6}{|l|}{ Pre-treatment process } \\
\hline Alum & $10-90$ & $\mathrm{mg} \mathrm{Fe}^{3+} / \mathrm{L}$ & 62.5 & $\mathrm{~g} \mathrm{Fe}^{3+}$ & Water Treatment Chemicals (2009) \\
\hline Polymer & 0.700 & $\mathrm{mg} / \mathrm{L}$ & 0.875 & $g$ & Cadee et al. (2011) \\
\hline Energy for treatment & 0.020 & $\mathrm{kWh} / \mathrm{kL}$ & 0.02 & kWh & Goldstein and Smith (2002) \\
\hline \multicolumn{6}{|l|}{ Electrodialysis process } \\
\hline CR67, MK111 & $8.40 \times 10^{-11}$ & meq/g dry membrane & $1.05 \times 10^{-10}$ & $g$ & $\begin{array}{l}\text { Sadrzadeh and Mohammadi (2007, } \\
\text { 442) }\end{array}$ \\
\hline AR204SXR412 & $9.80 \times 10^{-11}$ & meq/g dry membrane & $1.22 \times 10^{-10}$ & $g$ & $\begin{array}{l}\text { Sadrzadeh and Mohammadi (2007, } \\
\text { 442) }\end{array}$ \\
\hline Energy for treatment & $1.2-2.5$ & $\mathrm{kWh} / \mathrm{m}^{3}$ & 2.3 & kWh & Pilat $(2001,388)$ \\
\hline Brine & $10-20$ & $\%$ & 0.18 & $\mathrm{~kL}$ & Pilat $(2001,388)$ \\
\hline \multicolumn{6}{|l|}{ Post-treatment process } \\
\hline Chlorine & $2-10$ & $\mathrm{mg} / \mathrm{L}$ & 6.4 & g & Water Treatment Chemicals (2009) \\
\hline Fluorine & $0.7-1.2$ & $\mathrm{mg} / \mathrm{L}$ & 1.0 & $g$ & Water Treatment Chemicals (2011) \\
\hline Lime & $10-20$ & $\mathrm{mg} / \mathrm{L}$ & 15.9 & g & Water Treatment Chemicals (2011) \\
\hline Energy consumption & 0.00004 & $\mathrm{kWh} / \mathrm{kL}$ & 0.00004 & kWh & Goldstein and Smith (2002) \\
\hline \multicolumn{6}{|l|}{ Distribution process } \\
\hline Energy consumption & 0.318 & kWh/kL & 0.318 & kWh & Goldstein and Smith (2002) \\
\hline
\end{tabular}

the direct current (DC) potential is connected on both of the electrodes, it will cause the separation of ion to occur by forcing the ion to migrate through either AEM or CEM. Figure 2 shows the ion separation in the ED cell in order to produce dilute with reduced level of salts or desalinated water. The amount of inputs required for operating the electrodialysis and pre- and post-treatment process have been presented in the LCI (Table 3).

The energy consumption for extracting seawater and surface water has been considered to be $0.032 \mathrm{kWh} / \mathrm{kL}$, while $0.041 \mathrm{kWh} / \mathrm{kL}$ has been considered for groundwater (Goldstein and Smith 2002). The energy consumption of treated water delivery has been considered to be the 


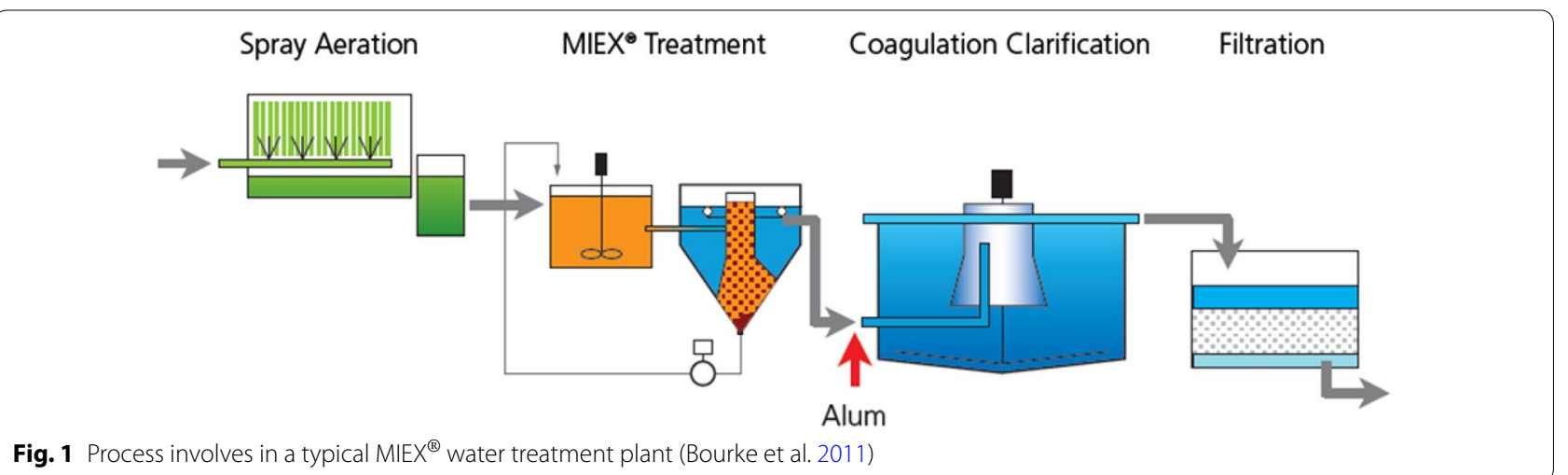

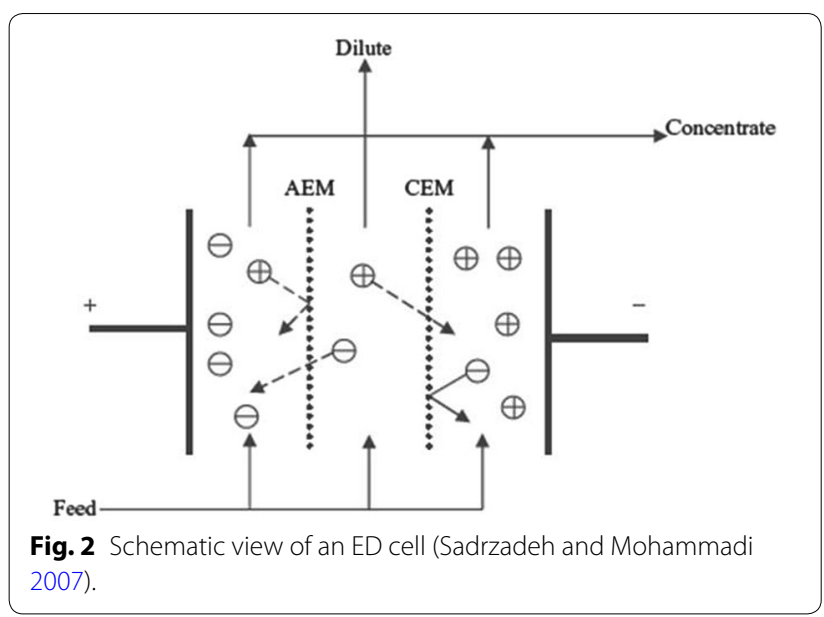

same for all water sources (i.e., $0.318 \mathrm{kWh} / \mathrm{Kl}$ ) (Goldstein and Smith 2002).

\section{Life cycle impact assessment (LCIA)}

Impact assessment is the conversion of GHGs associated with the production and use of inputs to $\mathrm{CO}_{2}$ equivalent $\left(\mathrm{kg} \mathrm{CO}_{2}\right.$-e) amount of global warming impacts carbon footprint. Simapro 8.02 LCA software was used to generate the GHG emissions from different water treatment plants (PRé Consultants 2015). The input data in the inventory were inserted into the LCA software to determine the global warming impacts. The database of Australian LCA has been used to calculate the GHG emissions from the production of chemical inputs (Life Cycle Strategies Pty Ltd. 2015). The results obtain from the LCIA will reveal which of the process route has raised higher GHG emissions.

In order to make the GHG emission results more representative for Western Australia, local emission databases have mostly been used. In the absence of local databases,
Ecoinvent databases were used to carry out the analysis. When neither a local nor a foreign database was available in the Simapro software for a particular product, a new emission database was created by obtaining GHG emission information from the literature (e.g., MIEX ${ }^{\circledR}$ Resin in this current LCA analysis).

The emission databases for chemicals is the Australian LCA database (Life Cycle Strategies Pty Ltd. 2015), which was used to calculate GHG emissions from the production of chemical inputs, such as chlorine, polymer and sodium chloride. Only in few cases, the emission factor for alum and fluorine were obtained from the Ecoinvent database (Hans-Jorg 2010), as local databases were unavailable.

An Australian study has been used to determine greenhouse gas emissions from the production of membrane for microfiltration while Mrayed and Leslie's study was used for emissions from membranes (Mrayed and Leslie 2009).

The emission databases for Western Australian electricity generation was used to calculate the greenhouse gas emissions (Life Cycle Strategies Pty Ltd. 2015).

Simapro software calculated the greenhouse gas emissions once the inputs and outputs were linked to the relevant libraries. The program sorted greenhouse gas emissions from the selected libraries/databases and then converted each selected greenhouse gas to $\mathrm{CO}_{2}$ equivalents $\left(\mathrm{CO}_{2}\right.$-eq). Impact values of global warming are expressed over 20-, 100- and 500-year time horizons to enable policy makers to make relevant climate change decisions. Accordingly, individual greenhouse gas $\left(\mathrm{CO}_{2}\right.$, $\mathrm{CH}_{4}$ and $\mathrm{N}_{2} \mathrm{O}$ ) emissions from each production stage were converted to $\mathrm{CO}_{2}$-eq using established conversion factors for 20-, 100- and 500-year time horizons (IPCC 2013). But we only used 100-year horizon for converting GHGs to $\mathrm{CO}_{2}$-eq as it is considered as the reference for climate change policy (UNFCCC 1992; Fearnside 2002). 


\section{Interpretation}

Interpretation is the step where the outcomes from the inventory analysis and impact assessment are evaluated in detail and come out with a conclusion for the best product or process route selection by compromising the uncertainty and the assumptions made throughout the LCA analysis. It finds out which input in the LCI in the water supply option is causing most GHG emissions in the water treatment and delivery process so that the appropriate mitigation strategy can be identified. The process flow network in the Simapro 8.02 LCA software has been used to find the breakdown of all inputs in terms of GHG emissions to find out the hotspot.

\section{Limitations}

The researcher consulted the Water Corporation of Western Australia during the time of the project to know about the details of groundwater and surface water treatment systems. The corporation was able to provide the processes and chemicals used in these treatment processes only. Therefore, the amount of chemicals and energy used in these processes were sourced from available credited published sources. Thus, it is considered to be a limitation of this research as field data were not used.

Foreign databases and generic values for emission factors of alum and fluorine have been used due to the absence of libraries of these materials in the Simapro software.

\section{Results and discussion}

Carbon footprint of three different water supply sources

Figure 3 shows the GHG emissions from the delivery of $1 \mathrm{~m}^{3}$ of water for groundwater, surface water and seawater sources in WA are $0.38 \mathrm{~kg} \mathrm{CO}_{2}$-e, $0.42 \mathrm{~kg} \mathrm{CO}_{2}$-e and $2.46 \mathrm{~kg} \mathrm{CO}$-e, respectively. From the results obtained, the GHG emissions from the seawater desalination treatment plant through ED technology is the most significant where it is about 6.5 and 5 times for the GHG emissions from Wanneroo GWTP and surface water treatment plant, respectively. Wanneroo GWTP has the least GHG emission, which is due to the advantage of the use of MIEX $^{\circledR}$ technology where lesser chemicals are required during the water treatment process. For comparison purposes, it was derived from Biswas (2009) that the GHG emissions from a newly commissioned reverse osmosis (RO) desalination plant in Bunbury and Kwinana, Western Australia, are $4.2 \mathrm{~kg} \mathrm{CO}_{2}$-eqq per $\mathrm{m}^{3}$ and $5.1 \mathrm{~kg}$ $\mathrm{CO}_{2}$-eq per $\mathrm{m}^{3}$, respectively, which are about 1.7 and 2.07 times higher than the ED or electrodialysis seawater desalination plant. This is because of the fact that RO operates at much higher pressure than ED, thus emitting additional GHG emissions due to increased electricity consumption.

\section{Carbon footprint of different stages of water production}

Figure 3 shows the breakdown of GHG contributions in terms of stages of water production and consumption

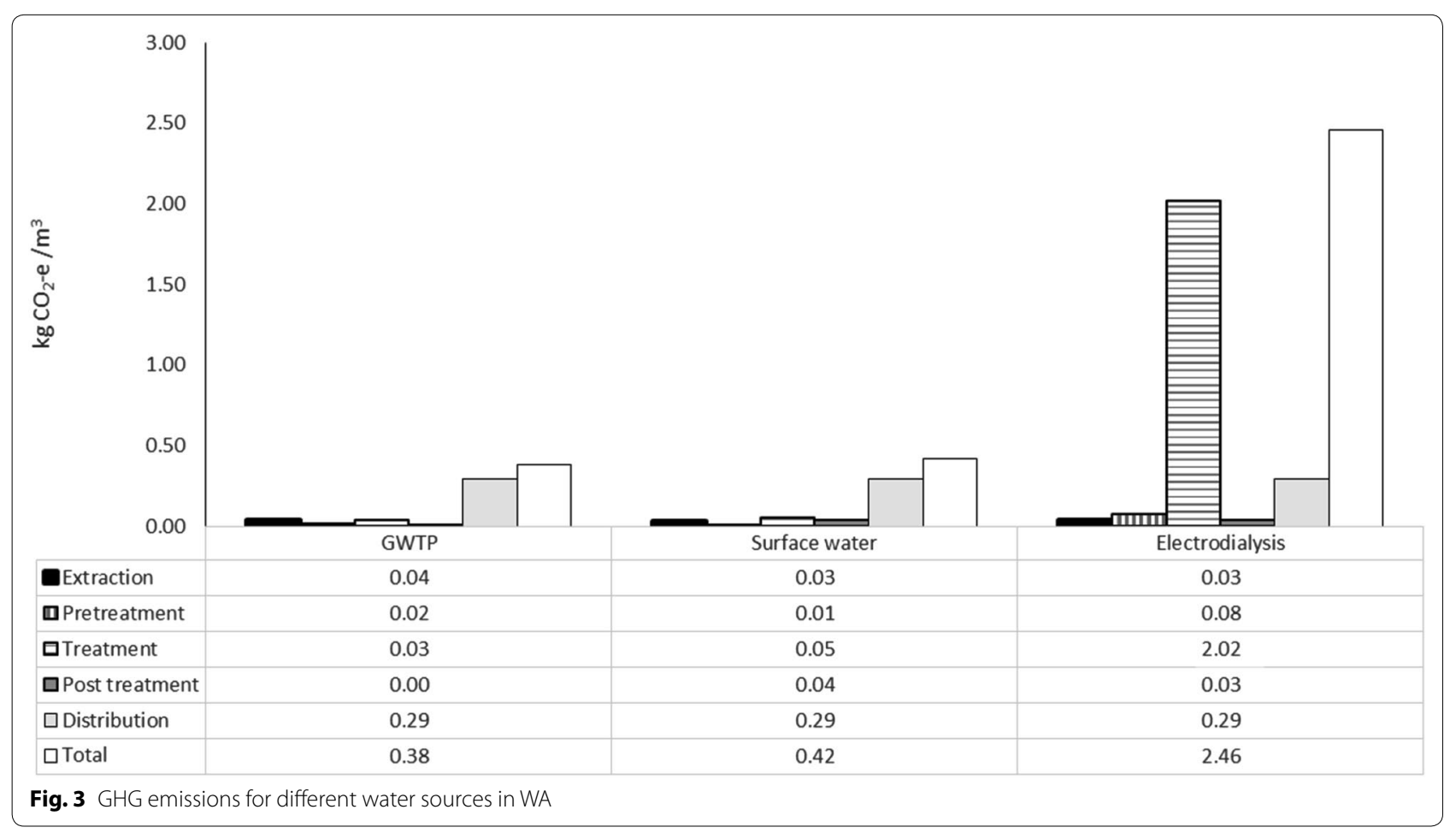


for three water supply options. In groundwater and surface water treatment processes, apparently the most significant GHG emission is via the distribution system. For the ED process, the most significant GHG emission stage is treatment process where $2.02 \mathrm{~kg}$ $\mathrm{CO}_{2}$-eq $\mathrm{m}^{3}$ is emitted. This is due to the energy-intensive ED technology. ED process is highly dependent on the movement for the electrically charged ions to move toward either positive or negative membranes (Carter 2001). Therefore, the energy demand for the ED treatment process is greatly proportional to the salt content in the seawater. In the extraction stage, the water extraction from the groundwater has the highest GHG emission which is $0.04 \mathrm{~kg} \mathrm{CO}_{2}$-eq per $\mathrm{m}^{3}$. This is owing to the higher energy consumption for the well pumping system which is $25 \%$ higher than the energy used for surface water extraction (Goldstein and Smith 2002).

This finding is similar to Racoviceanu et al. (2007) as the water treatment facilities phase has contributed the most GHG emission which is $0.12 \mathrm{~kg} \mathrm{CO}_{2}$-eq per $\mathrm{m}^{3}$ whereas the total GHG emission from the total energy use for a water treatment system is $0.13 \mathrm{~g} \mathrm{CO}_{2}$-eq per $\mathrm{m}^{3}$. Similar to the current study, this study found that chemical manufacturing stage $\left(0.045 \mathrm{~g} \mathrm{CO}_{2}\right.$-eq per $\left.\mathrm{m}^{3}\right)$ and chemical transportation phase $\left(0.01 \mathrm{~g} \mathrm{CO}_{2}\right.$-eq per $\left.\mathrm{m}^{3}\right)$ contributed only very small amount $(<10 \%)$ of GHG emissions from water treatment.

\section{Identification of hot spot}

Hotspot is defined as the major contribution to the environmental and social aspect in a life cycle phase for a process or a product. Identification of the hotspot in a specific life cycle is very important to apply mitigation strategy for carbon footprint reduction. In this case study, two main inputs which are electricity generation and chemicals used have been investigated for identifying the hotspot for different water treatment plants (Table 4).

For Wanneroo GWTP, the GHG emissions from the electricity generation and chemicals used are 95 and $5 \%$ of the total GHG emissions, respectively. Moreover, the electricity generation and chemicals used in the surface water treatment plant have emitted 82 and $18 \%$ correspondingly of GHG.

Table 4 Breakdown of GHG emissions ( $k g \mathrm{CO}_{2}$-e per $\mathrm{m}^{3}$ ) in terms of inputs

\begin{tabular}{llll}
\hline & GWTP & Surface water & Desalination \\
\hline Electricity & 0.36 & 0.34 & 2.41 \\
Chemicals and membranes & 0.02 & 0.08 & 0.05 \\
Total & 0.38 & 0.42 & 2.46 \\
\hline
\end{tabular}

In the seawater desalination plant via the electrodialysis (ED), $98 \%$ of the GHG emission is originated from the generation of electricity while $2 \%$ from the chemicals used. From the three sets of results obtained, the GHG emission from the electricity generation in the seawater desalination plant has contributed the highest percentage. This is owing to the energy intensity process of the electrodialysis process. A similar study carried out by Mrayed and Leslie (2009) found that the greenhouse gas emissions from the generation of electricity for the operation of seawater desalination plant accounted for a large proportion (95\%) of the total greenhouse gas emissions, followed by chemicals production (4\%). Also a North American study found that $90 \%$ of the GHG emissions came from electricity generation and the rest from chemicals (Racoviceanu et al. 2007).

\section{Mitigation strategy}

The main objective is to reduce GHG emissions from the biggest polluting water supply option (i.e., ED) to the level of existing groundwater and surface water treatment system in order to meet the required water demand for WA with no additional GHG emissions.

In order to reduce the GHG emissions from the hot spot, grid electricity that is predominantly generated from coal and natural gas has been considered to be replaced with the electricity generated from biomass, wind turbines and photovoltaic plants. These three renewable energy resources have been considered because close to $37 \%$ of Western Australia's electricity could be produced from wind, biomass and solar photovoltaic (PV) by 2030, up from around $8 \%$ currently (Clean Energy Council 2011).

In the case of WA's coastal area, wind is a low-cost and fast-growing source of renewable energy as costs of electricity generation from wind power is around $\$ 90-\$ 130 /$ MWh (Parkinson 2012), which is lower than the cost of electricity generation from solar PV (\$225-\$404/MWh) and solar thermal power plants (\$200-\$290/MWh) (Clean Energy Council 2011). Also in Western Australia most of the electricity generated by renewable resources comes from wind energy (The Climate Institute 2010). While current wind power production is insufficient to meet the needs of the ED plant in this case study, there is a significant potential for sourcing wind power to provide the total energy requirements of the plant to attain required carbon saving benefits.

Although biomass resource availability is considerably higher than wind for generating electricity in WA (Clean Energy Council 2011), the collection of the former is difficult due to their scattered locations. Considering these cost, technological and resource constraints, a scenario analysis has been considered for grid and renewable 
energy mix for wind, solar and biomass for providing electricity for water treatment through ED process and it will help policy makers in the decision-making process.

The maximum GHG emissions from the generation of electricity from biomass, wind turbines and PV are 18, 400, 9.7 and 217 tons $\mathrm{CO}_{2}$-eq per GWh energy generated, respectively (Lund and Biswas 2008). These emission factors have been considered when estimating GHG emissions from water treatment using renewable energy. Generally, the GHG emission can be reduced by 99,74 , 49 and $25 \%$ by substituting grid electricity with wind generated electricity by $100,75,50$ and $25 \%$, respectively (Fig. 4). The bioelectricity has the lowest GHG emission mitigation potential as only $54,40,27$ and $13 \%$ of the total GHG emission can be mitigated for substituting $100,75,50$ and $25 \%$ grid electricity with bioelectricity.

The comparison of three renewable energy scenarios shows that the electricity generated from the wind turbines can significantly reduce the GHG emissions from water production and consumption. If $100 \%$ of electricity which is generated from wind turbines is used for water production and delivery, approximately $99 \%$ of the total GHG emissions can be mitigated from three water treatment plants. Furthermore, the abilities of reducing the GHG emissions from the electricity generation via renewable energies are then followed by PV and biomass in the descending order. If there is $100 \%$ substitution of wind, PV and biomass renewable energies in the electricity generation, the GHG emissions can be reduced by 99 \% (i.e., $0.03 \mathrm{~kg} \mathrm{CO}_{2}$-eq), 75 \% (i.e., $0.61 \mathrm{~kg} \mathrm{CO}_{2}$-eq) and
$54 \%$ (i.e., $0.113 \mathrm{~kg} \mathrm{CO}_{2}$-eq), respectively. It shows that the generation of electricity entirely from solar PV and biomass cannot help reduce the GHG emission to the level of groundwater $\left(0.38 \mathrm{~kg} \mathrm{CO}_{2}-\mathrm{e}\right)$ and surface water $\left(0.42 \mathrm{~kg} \mathrm{CO}_{2}\right.$-eq) treatment options.

Although the use of $100 \%$ wind energy can result GHG emissions far below the level of GHG emission from these existing GWTP and surface water treatment plants, the consideration of $100 \%$ electricity generation from wind is a challenging task given its intermittent nature and availability potential. Therefore, it was derived from these results that $15 \%$ grid and $85 \%$ wind for electricity generation can reduce the GHG emission of ED to $0.39 \mathrm{~kg} \mathrm{CO}_{2}$-e per $\mathrm{m}^{3}$, which is around the same level of GHG emissions produced by groundwater (or GWTP) and surface water treatment plants.

\section{Conclusions}

The life cycle assessment results show that the GHG emissions from electrodialysis desalination water treatment plant $\left(2.46 \mathrm{~kg} \mathrm{CO}_{2}\right.$ eq per $\left.\mathrm{m}^{3}\right)$ is 6.5 and 6 times higher than the existing GWTP and surface water treatment plants due to energy-intensive treatment process. Wanneroo GWTP has the least GHG emission, which is due to the advantage of the use of MIEX ${ }^{\circledR}$ technology where lesser chemicals are required during the water treatment process.

From the life cycle assessment performed in this case study, the hotspot of the GHG emissions from the three water treatment plant is the electricity generation where it contributes 95, 82 and $98 \%$ of total GHG emissions

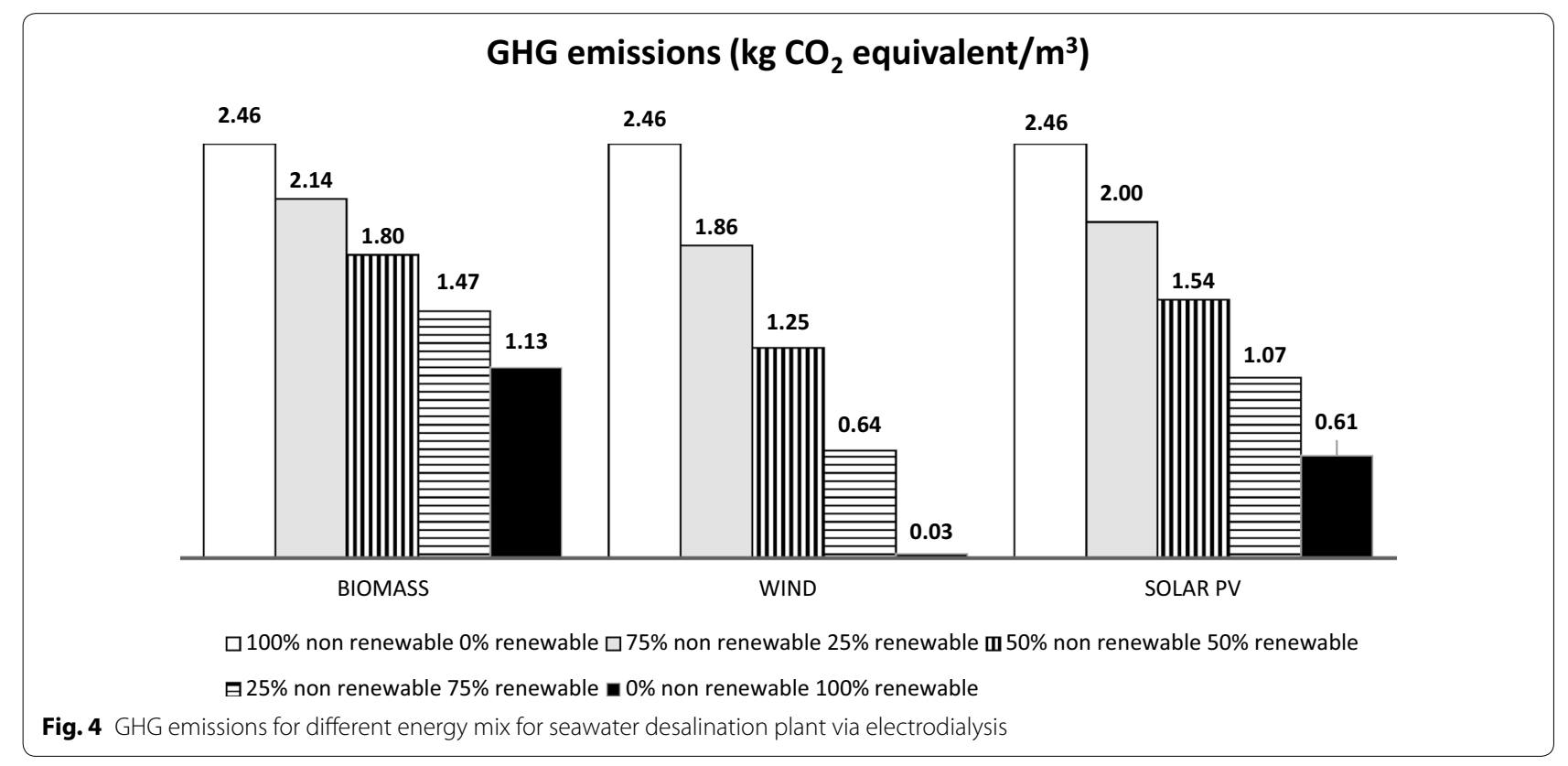


in Wanneroo GWTP, surface water treatment plant and electrodialysis seawater desalination plant. Therefore, cleaner production strategy of input substitution has been applied to reduce the carbon footprint. Renewable energies of biomass, wind and photovoltaic are introduced to replace the natural resources such as black coal and natural gas in the electricity generation stage. By using $100 \%$ renewable energy, 97, 92 and $89 \%$ of GHG emissions can be reduced via wind turbines, photovoltaic and biomass, respectively. Lastly, based on the LCA performed, the best water supply system is the Wanneroo GWTP as it is having the smallest carbon footprint among the water supply systems.

Solar and biomass have not been found to be as promising as wind for providing electricity for reducing GHG emissions of ED further to the level of GHG emissions from groundwater and surface water treatment options. Since $100 \%$ of the electricity generated from wind would be a challenging task, a maximum of $85 \%$ substitution of grid electricity by wind could just reduce GHG emissions of ED to the level of existing water treatment options.

\section{Authors' contributions}

WKB had conducted the LCA, reviewed literature andcontributed to paper writing. PY had developed the inventory, conducted theanalysis and prepared the initial draft required for this paper. Both authors read and approved the final manuscript.

\section{Author details}

${ }^{1}$ Sustainable Engineering Group, Curtin University, Perth, WA 6102, Australia. ${ }^{2}$ Department of Chemical Engineering, Curtin University, Perth, WA 6102, Australia.

\section{Competing interests}

The authors declare that they have no competing interests.

Received: 17 February 2016 Accepted: 22 August 2016

Published online: 08 September 2016

\section{References}

AFFA (Agriculture, Fisheries \& Forestry—Australia). (2002). Economic and technical assessment of desalination technologies in Australia: With particular reference to National Action Plan Priority Regions. In Agriculture, Fisheries \& Forestry - Australia, Northbourne Avenue Turner ACT 2612.

Barber, W. P. F. (2008). Modeling the carbon footprint of various biosolids treatment options. In Proceedings of the Water Environment Federation (pp. 7787-7807). Water Environment Federation.

Biswas, W. K. (2009). Life cycle assessment of seawater desalination in Western Australia. World Academy of Science Engineering and Technology, 35, 369-375.

Bourke, M., Slunjski, M., O'Leary, B., \& Smith, P. (2011). Scale-up of the MIEX ${ }^{\circledR}$ DOC process for full scale water treatment plants. http://www.miexresin.com/ business/che/watercare/rwpattach.nsf/PublicbySrc/WanAUSAWAFC99. pdf/\$file/WanAUSAWAFC99.pdf. Accessed 31 Oct 2011.

Cadee, K., O'Leary, B., Smith, P., Slunjski, M., \& Bourke, M. (2011). World's first magnetic ion exchange (MIEX) water treatment plant to be installed in Western Australia. http://www.miexresin.com/files/publishedPapers/ Worlds_First_AWWA_2000.pdf. Accessed 20 Jun 2011.

Carter, N.T. (2001). Desalination: Technologies, use, and congressional Issues. Congressional Research Service, 7-5700, www.crs.gov, R40477. http://www. fas.org/sgp/crs/misc/R40477.pdf. Accessed 20 Oct 2011.
Clean Energy Council. (2011). Review of the Australian wind energy 2011. Melbourne, VIC: Clean Energy Council.

Coday, B. D., Miller-Robbie, L., Beaudry, E. G., Munakata-Marr, J., \& Cath, T. Y. (2015). Life cycle and economic assessments of engineered osmosis and osmotic dilution for desalination of Haynesville shale pit water. Desalination, 369, 188-200.

de Haas, D., Foley, J., \& Lant, P. (2009). Energy and greenhouse footprints of wastewater treatment plants in south-east Queensland. In Presented at AWA Ozwater'09 Conference, Melbourne, 16-19 March.

Fearnside, P. M. (2002). Why a 100-year time horizon should be used for global warming mitigation calculations. Mitigation and Adaptation Strategies for Global Change, 7, 19-30.

Foley, J., de Haas, D., Hartley, K., \& Lant, P. (2007). Life cycle assessment of biological nutrient removal wastewater treatment plants. In 3rd International conference on life cycle management, Zurich, University of Zurich at Irchel, 27-29 August.

Foley, J., de Haas, D., Hartley, K., \& Lant, P. (2010). Comprehensive life cycle inventories of alternative wastewater treatment systems. Water Research, 44, 1654-1666.

Goldstein, R., \& Smith. W. (2002). Water \& sustainability (Volume 4): U.S. electricity consumption for water supply \& treatment - The Next HalfCentury. http:// www.circleofblue.org/waternews/wp-content/uploads/2010/08/EPRIVolume-4.pdf. Accessed 30 May 2011.

Greensboro Water Resources. (2011). Water treatment chemicals. http://www. greensboroncgov/departments/Water/watersystem/chemicals.htm. Accessed 20 Oct 2011.

Hall, M. R., West, J., Sherman, B., Lane, J., \& de Haas, D. (2011). Long-term trends and opportunities for managing regional water supply and wastewater greenhouse gas emissions. Environmental Science and Technology, 45, 5434-5440.

Hans-Jorg, A. (2010). Ecoinvent unit processes for Simapro, life cycle assessment and modelling group. Switzerland: Dübendorf. 2010.

Hardisty, P. E., Sivapalan, M., \& Humphries, R. (2013). Determining a sustainable and economically optimal wastewater treatment and discharge strategy. Journal Environmental Management, 114, 285-292.

Ho, G., \& Anda, M. (2006). Centralised versus decentralised wastewater systems in an urban context: The sustainability dimension, In 2nd IWA leading edge on sustainability in water-limited environments. IWA Publishing, 81-89.

IPCC. (2013). Climate change 2013: The physical science basis. In Contribution of working group I to the fifth assessment report of the intergovernmental panel on climate change. Stocker

ISO. (2007). Environmental management_Life cycle assessment_-Principles and framework. ISO 14040, International Organization for Standardization (ISO), Geneva

Lange, R., Tattersall, J., Botica, C., Smith, P. (2011). Design and construction of the world's first large scale MIEX $X^{\circledR}$ water treatment plant. http://www. miexresin.com/files/publishedPapers/WanAUSAWAFC01.pdf. Accessed July 27.

Lane, J., de Haas, D., \& Lant, P. (2010). Life cycle analysis of the Gold Coast Urban Water Cycle Science Forum and stakeholder engagement. Brisbane, Queensland: Urban Water Security Research Alliance.

Lenntech, B.V. (2009). Water treatment chemicals. In T.F., Qin, D., Plattner, G.K., Tignor, M., Allen, S.K., Boschung, J., Nauels, A., Xia, Y., Bex, V., Midgley, P.M. (Eds.), Lenntech BV, Rotterdamseweg, 402 M 2629HH Delft. Cambridge University Press, Cambridge, p. 1535

Life Cycle Strategies Pty Ltd (2015) Australasian Unit Process LCI Library and Methods. Version 2015_02_06. http://www.lifecycles.com. au/\#!australasian-database/cbm5. Accessed 30 Jun 2015.

Lund, C., \& Biswas, W. K. (2008). A Review of the Application of Lifecycle Analysis to Renewable Energy Systems. Bulletin of Science, Technology \& Society, 28, 200-209.

Lundie, S., Peters, G. M., \& Beavis, P. C. (2004). Life cycle assessment for sustainable metropolitan water systems planning. Environmental Science and Technology, 38, 3465-3473.

Mercer, D. (2009). Perth heading of water crisis. In The West Australian, 19 December. http://au.news.yahoo.com/thewest/a/-/breaking/6605147/ perth-heading-for-water-crisis/. Accessed 20 Jun 2011.

Mrayed, S., \& Leslie, G. (2009). Examination of greenhouse footprint for both desalination and water recycling processes. Melbourne: Ozwater09.

Parkinson, G.A. (2012). Smart grid and seven clean energy sources. Reneweconomy. http://reneweconomy.com. 
au/2012/a-smart-grid-and-seven-clean-energy-sources-31471. Accessed 10 Sept 2013.

Perth Seawater Desalination Plant. (2006). Seawater Reverse Osmosis (SWRO), Kwinana, Australia. In The Traveston Swamp News, 11 November. http:// swampnews.squarespace.com/media-watch2/2006/11/11/perth-seawater-desalination plant-seawater-reverse-osmosis-swro-kwinana-australia. html. Accessed 7 Apr 2012.

Pilat, B. (2001). Practice of water desalination by electrodialysis. Desalination, $139,385-392$.

PRé Consultants. (2015). Simapro Version 8.02. The Netherlands: PRé Consultants.

Racoviceanu, A., Bryan, W. K., Kennedy, C. A., \& Colombo, A. F. (2007). Life-cycle energy use and greenhouse gas emissions inventory for water treatment systems. Journal of Infrastructure Systems, 13, 261-270.

Raluy, R. G., Serra, L., \& Uche, J. (2005). Life cycle assessment of desalination technologies integrated with renewable energies. Desalination, 183, 81-93.

Sadrzadeh, M., \& Mohammadi, T. (2007). Seawater desalination using electrodialysis. Desalination, 221, 440-447.

Shahabi, M. P., Anda, M., \& Ho, G. (2015a). Influence of site-specific parameters on environmental impacts of desalination. Desalination Water Treatment, 55, 2357-2363.

Shahabi, M. P., McHugh, A., Anda, M., \& Ho, G. (2014). Environmental life cycle assessment of seawater reverse osmosis desalination plant powered by renewable energy. Renewable Energy, 67, 53-58.

Shahabi, M. P., McHugh, A., Anda, M., \& Ho, G. (2015b). Comparative economic and environmental assessments of centralised and decentralised seawater desalination options. Desalination, 376, 25-34.
Shahabi, M. P., McHugh, A., \& Ho, G. (2015c). Environmental and economic assessment of beach well intake versus open intake for seawater reverse osmosis desalination. Desalination, 357, 259-266.

Slunjski, M., Cadee, K., \& Tattersall, J. (2011). MIEX ${ }^{\circledR}$ Resin water treatment process. http://csiropedia.csiro.au/download/attachments/426149/ AquatechNL2000.pdf? version=1\&modificationDate $=1297904233697$. Accessed 20 Aug 2011

Stokes, J., \& Horvath, A. (2006). Life cycle energy assessment of alternative water supply systems (9 pp). International Journal of Life Cycle Assessment, $11,335-343$.

Taylor, R. (2010). Population boom to strain Perth, The West Australian, 22 March. http://au.news.yahoo.com/thewest/a/-/breaking/6961372/ population-boom-to-strain-perth/.

The Climate Institute. (2010). Clean energy job in regional Australia. Sydney: The Climate Institute.

UNFCCC. (1992). United Nations framework convention on climate change. Germany: United Nations Framework Convention on Climate Change.

Thompson, P., \& Waite, A. (2003). Phytoplankton responses to wastewater discharges at two sites in Western Australia. Marsh \& Freshwater Research, $54,721-735$.

Water Corporation. (2011). Perth Residential Water Use Study 2008/2009. http:// www.thinking50.com.au/download.cfm?DownloadFile=EE312328-9536B357-D0D8F8E729426F2C. Accessed 7 Apr 2012.

Water Corporation. (2015). What is the integrated water supply scheme, water corporation, Perth. http://www.watercorporation.com.au/home/faqs/ water-supply-and-services/what-is-theintegrated-water-supply-scheme. Accessed 20 Oct 2015.

Yoshida, H., Christensen, T. H., \& Scheutz, C. (2013). Life cycle assessment of sewage sludge management: A review. Waste Management and Research, 13, 1083-1101.

\section{Submit your manuscript to a SpringerOpen ${ }^{\circ}$ journal and benefit from:}

- Convenient online submission

- Rigorous peer review

- Immediate publication on acceptance

- Open access: articles freely available online

- High visibility within the field

- Retaining the copyright to your article

Submit your next manuscript at $\boldsymbol{\nabla}$ springeropen.com 